\title{
FEEDING CAPACITY AND HOST PREFERENCE OF Chrysoperla carnea (Stephens) (Neuroptera: chrysopidae) ON THREE DIFFERENT INSECT PREY UNDER LABORATORY CONDITIONS. Hassan, K. A. \\ Bollworm Dept ., Plant Protection Research Institute, ARC, Dokki, Giza- Egypt.
}

\begin{abstract}
Laboratory trials of feeding potential of Chrysoperla carnea (Steph.) (No choice) were estimated at $\left(25 \pm 2{ }^{\circ} \mathrm{C}, 65 \pm 5 \% \mathrm{R}\right.$. H. $)$. Data revealed that the larval stage of C. carnea (Steph.) fed on egg masses of Corcyra cephalonica (St.) Pectinophora gossypiella (Saund.) and Sitotroga cerealella (Oliv.) consuming all over its 3 larval instars an average of $493.6 \pm 50.32,654.3 \pm 32.54$ and $673.9 \pm 31.52$ eggs (total consumed) for the three prey species, respectively, with total larval corresponding periods $8.7 \pm 0.94,9.5 \pm 0.97$ and $9.6 \pm 1.17$ days. Statistical analysis of the obtained data obviously cleared that there were significance differences between the mean numbers of consumed $C$. cephalonica eggs and that of $P$. gossypiella and $S$. cerealella; on the other hand there was no significance of $C$. carnea total larval period when feeding upon each of the three preys. In addition, host preference (Free Choice) revealed that $C$. cephalonica was the most preferred host to C. carnea. The predator consumed $(13.2 \pm 6.01,77.9 \pm 31.14$ and $264.1 \pm 68.8$ eggs of $C$. cephalonica for the $1^{\text {st }}, 2^{\text {nd }}$ and $3^{\text {rd }}$ predator larval instars, respectively). $S$. cerealella was the least preferred host, whereas the respective predator larval instars consumed $(0.8 \pm 1.75,27.9 \pm 24.56$ and $63.3 \pm 47.2$ eggs $)$. Also, numbers of attacked eggs by the predator was recorded. Eggs of Rice moth were the highest attacked with Green Lacewing larvae while eggs of Angoumois grain moth were the least. This result needs more experimental efforts to earn its advantage in certain predacious performance.

Keywords: Green lacewing, Chrysoperla carnea, insect preys, host preference, choice, PBW,Pectinophora gossypiella , Rice moth, Corcyra cephalonica, Angoumois grain moth, Sitotroga cerealella.
\end{abstract}

\section{INTRODUCTION}

The green lacewings, Chrysoperla carnea (Stephens) ((Chrysopidae: Neuroptera), is a cosmopolitan polyphagous predator, commonly found in a wide range of agricultural systems. Larvae of $C$. carnea are voracious and efficient biological control agents for aphid and various phytophagous arthropods because of its ubiquitous nature, polyphagous habits, and compatibility with selected chemical insecticides and microbial agents (Ridgway and Murphy, 1984; Obrycki et al., 1989; Yuksel and Goemen, 1992; Singh and Manoj, 2000 Venkatesan et al., 2000, 2002; Zaki and Gesraha, 2001; McEwen et al.2001and Uddin et al., 2005.)

It is important for the successful development of pest management programs that utilize $C$. carnea as a biocontrol agent to identify alternative high quality prey/food. There are no many studies on the effect of different prey species on the biology, life table parameters, fecundity and adult 
Hassan, K. A.

longevity of $C$. carnea, despite its importance as a predator of aphid pests. Osman and Selman (1996) reported that Lepidoptera eggs have a high nutritional quality for lacewing. The importance of the nutritional quality of the prey for this predator needs more attention.

The aim of the present study was to evaluate three different prey species (Corcyra cephalonica, Pectinophora gossypiella and Sitotroga cerealella) as food for $C$. carnea in terms of survival and development under laboratory conditions to determine the potential of this predator. Consequently, the second objective of this study was to evaluate the prey preference. Such information would be helpful for optimizing the mass rearing of $C$. carnea.

\section{MATERIALS AND METHODS}

\section{1-Predator rearing:}

Chrysoperla carnea: Adults of Green lacewing was collected from cotton fields and kept in the laboratory conditions $\left(25 \pm 2{ }^{\circ} \mathrm{C} \& 65 \pm 5 \%\right.$ R. H. $)$ in plastic boxes $(22 \times 13 \times 10 \mathrm{~cm})$ covered with black muslin for egg deposition and fed on droplet of semi artificial diet (2 yeast extract: 1 fructose: 1 distilled water) provided once a day on sticky tape with help of fine brush. The laid eggs were collected daily and kept under the same conditions. The neonate was maintained and provided with eggs of Angoumois grain moth, Sitotroga cerealella. Many generations on the course of three successive years, C. carnea were reared in the laboratory. For the present experiments C. carnea adults were obtained from the laboratory colony. The adults were sexed into males \& females and 10 pairs of adults were placed in covered plastic boxes for egg laying .Newly hatched larvae were used in the trials.

2-Preys rearing:

a-Sitotroga cerealella: The method of rearing of Angoumois grain moth was a modification of those postulated by Hassan (1995) where soft wheat was provided as a rearing medium.

b-Pectinophora gossypiella: Pink bollworm (PBW) was reared in the laboratory under controlled conditions without exposure to insecticides for several generations on modified artificial diet as described by Abd ElHafez et al. (1982) .

c-Corcyra cephalonica: Fresh Rice moth eggs were obtained from

"Aswan Organic Agricultural Services Center" kept in ice box to be used before hatching.

\section{3- Feeding capacity of of $\boldsymbol{C}$. carnea on three different prey species (No} choice):

Feeding efficiency of $C$. carnea larval instars, $1^{\text {st }}, 2^{\text {nd }}$ and $3^{\text {rd }}$ was studied on the eggs of $C$. cephalonica, P. gossypiella and S. cerealella separately. Experiments were carried out in the laboratory (Plant Protection Research Institute Dokki-Giza). $1^{\text {st }}$ instar larvae of $C$. carnea were given 50 eggs, using glass tubes $(2 \times 7 \mathrm{~cm}$.) tightly closed with compressed cotton piece of $C$. cephalonica, $P$. gossypiella and $S$. cerealella. Ten replicates were used / prey species. The same previous technique was used for the $2^{\text {nd }}$ and $3^{\text {rd }}$ instars evaluation, taking in account duplication of egg masses for each 
prey to estimate number of consumed eggs for each prey species as well as estimation of number of attacks for each instar and each prey species. The following parameters were recorded daily: number of consumed eggs number of attacks, and duration of predator larval instars.

\section{4- Host preference of of $C$. carnea on three different prey species (Free} Choice):

For host preference $1^{\text {st }}$ instar larvae of $C$. carnea were given 50 eggs (in the form of 3 patches of C. cephalonica, P. gossypiella and S. cerealella distributed in a petri dish $(6 \times 12 \mathrm{~cm})$ keeping equal distances from each other and from the larvae which placed in the center of the dish) .Ten replicates were used in the experiment. Numbers of moving the predator $C$. carnea towards each prey species were estimated 6 times during the first 3 hours. The movements were taken as indicator for the number of attacks against the three preys' species, i.e. how many times the predator headed towards the prey). The same previous technique was used for the $2^{\text {nd }}$ and $3^{\text {rd }}$ instars evaluation, taking in account duplication of egg masses for each prey species as mentioned before. Number of consumed eggs and numbers of the predator attacks against each prey species were estimated to both $2^{\text {nd }}$ and $3^{\text {rd }}$ instars. It is important to note that after all the predator larvae trials for feeding there must be remaining of eggs in each egg patch for the three prey species to ensure that the predator larvae are completely satiated. Also, in all case care was taken to prevent predator injury during transferring them to glass tubes or petri dishes.

\section{Statistical analysis:}

Analysis of variance was done on all estimated data (ANOVA) and Duncan's multiple range tests was used to separate the means (Snedecor \& Cochran 1980).

\section{RESULTS AND DISCUSSION}

\section{1-Feeding capacity of $C$. carnea (No choice):}

Data given in (Table 1) indicated that the $1^{\text {st }}$, the $2^{\text {nd }}$ and the $3^{\text {rd }}$ instars of $C$. carnea fed on egg masses of $C$. cephalonica, $P$. gossypiella and $S$. cerealella consuming mean numbers of eggs $(22.4 \pm 2.99,30.3 \pm 4.34 \& 32.5$ $\pm 5.49) ;(129.0 \pm 20.1,169.1 \pm 14.42 \& 165.4 \pm 28.4)$ and $316.8 \pm 33.14$, $440.4 \pm 30.91 \& 461.8 \pm 44.6$ ) for the three larval instars upon the three preys species, respectively, the total consumption was $(493.6 \pm 50.32,654.3 \pm 32.54$ and $673.9 \pm 31.52)$ for the three prey species with total larval corresponding periods $(8.7 \pm 0.94,9.5 \pm 0.97$ and $9.6 \pm 1.17$ days) for each prey species. The statistical analysis revealed that there was a significance difference between the mean total number of consumed $C$. cephalonica eggs and that of $P$. gossypiella and S. cerealella eggs. Findings of Syed et al. (2005) indicated that $C$. carnea consumed more Bemisia tabaci (200.5 nymphs) as compared to Amrasca devastans (171.8 nymphs). 
Hassan,K. A.

Table (1): Feeding capacity and duration period of $C$. carnea larvae when fed on three different preys.

\begin{tabular}{|l|c|c|c|c|c|c|c|c|}
\hline \multirow{3}{*}{ instars } & \multicolumn{3}{|c|}{ Mean numbers of preys consumed eggs* } & \multicolumn{3}{c|}{$\begin{array}{c}\text { Larval duration of predator* } \\
\text { (Mean } \pm \text { S.E.) }\end{array}$} \\
\cline { 2 - 8 } & $\begin{array}{c}\boldsymbol{C} \text {. } \\
\text { cephalonica }\end{array}$ & $\begin{array}{c}\boldsymbol{P} \text {. } \\
\text { gossypiella }\end{array}$ & $\begin{array}{c}\text { S. } \\
\text { cerealella }\end{array}$ & $\begin{array}{c}\text { L.S.D } \\
\text { cephalon } \\
\text { ica }\end{array}$ & $\begin{array}{c}\text { C. } \\
\text { gossypiell } \\
\boldsymbol{a}\end{array}$ & $\begin{array}{c}\text { S. } \\
\text { cerealella }\end{array}$ & L.S.D \\
\hline $1^{\text {st }}$ & $22.4 \pm 2.99 \mathrm{~b}$ & $30.3 \pm 4.34 \mathrm{a}$ & $32.5 \pm 5.49 \mathrm{a}$ & 2.31 & $2.5 \pm 0.5 \mathrm{~b}$ & $3.4 \pm 0.5 \mathrm{a}$ & $2.6 \pm 0.5 \mathrm{~b}$ & 0.48 \\
\hline $2^{\text {nd }}$ & $129.6 \pm 20.1 \mathrm{~b}$ & $169.1 \pm 14.42 \mathrm{a}$ & $165.4 \pm 28.4 \mathrm{a}$ & 11.5 & $2.6 \pm 0.53 \mathrm{a}$ & $2.7 \pm 0.5 \mathrm{a}$ & $2.5 \pm 0.7 \mathrm{a}$ & 0.53 \\
\hline $3^{\text {rd }}$ & $316.8 \pm 33.14 \mathrm{~b}$ & $440.4 \pm 30.91 \mathrm{a}$ & $461.8 \pm 44.6 \mathrm{a}$ & 19.5 & $3.4 \pm 0.52 \mathrm{a}$ & $3.6 \pm 0.5 \mathrm{a}$ & $3.9 \pm 0.9 \mathrm{a}$ & 0.60 \\
\hline total & $493.6 \pm 50.32 \mathrm{~b}$ & $654.3 \pm 32.54 \mathrm{a}$ & $673.9 \pm 31.52 \mathrm{a}$ & 35.87 & $8.7 \pm 0.94 \mathrm{a}$ & $9.5 \pm 0.97 \mathrm{a}$ & $9.6 \pm 1.17 \mathrm{a}$ & 0.95 \\
\hline
\end{tabular}

*Means followed by the same letter at the same row in both preys consumed eggs and larval duration of predator are not significantly different at $\mathbf{P}=\mathbf{0 . 0 5}$.

On the other hand, there was no-significance difference of $C$. carnea total larval period when feeding upon each of the three preys (Table 1). The present results concerning larval period disagree with Balasubramani \&Swamiappan (1994) who reported that the larval development of C. carnea on different hosts in laboratory was rapid on eggs of $C$. cephalonica and longest on neonates of the American bollworm, Helicoverpa armigera. Also, Mannan et al. (1997) observed that larval duration was long when fed on Myzus persicae than Aphis gossypii. The disagreement may be due to the differences of the prey species or the laboratory conditions.

2-Host preference of $\boldsymbol{C}$. carnea (Free Choice):

Table (2) \& Figure (1) summarize the host preference of the Green lacewing during its larval stages. C. cephalonica was the highly preferred host of $C$. carnea with no difference through the $1^{\text {st }} \& 2^{\text {nd }}$ larval instars than PBW eggs. The $1^{\text {st }}, 2^{\text {nd }}$ and $3^{\text {rd }}$ predator larval instars consumed $13.2 \pm 6.01$, $77.9 \pm 31.14$ and $264.1 \pm 68.8$ eggs of $C$. cephalonica, respectively; whereas S. cerealella

Table (2): Host preference of the Green lacewing C. carnea (Free Choice)

\begin{tabular}{|l|c|c|c|c|}
\hline \multirow{2}{*}{ Larval stage } & \multicolumn{4}{|c|}{ Mean numbers of preys consumed eggs \pm S.D. ${ }^{*}$} \\
\cline { 2 - 5 } & C. cephalonica & P. gossypiella & S. cerealella & L.S.D \\
\hline $1^{\text {st }}$ instar & $13.2 \pm 6.01 \mathrm{a}$ & $10.8 \pm 5.83 \mathrm{a}$ & $0.8 \pm 1.7 \mathrm{~b}$ & 2.61 \\
\hline $2^{\text {nd }}$ instar & $77.9 \pm 31.14 \mathrm{a}$ & $65.7 \pm 35.6 \mathrm{a}$ & $27.9 \pm 24.56 \mathrm{~b}$ & 16.31 \\
\hline $3^{\text {rd }}$ instar & $264.1 \pm 68.8 \mathrm{a}$ & $111.2 \pm 56 \mathrm{~b}$ & $63.3 \pm 47.30 \mathrm{c}$ & 30.82 \\
\hline
\end{tabular}

*Means followed by the same letter at the same row in preys consumed eggs are not significantly different at $\mathbf{P}=\mathbf{0 . 0 5}$.

was significantly the least preferred host in free choice preference. The respective predator larval instars consumed $(0.8 \pm 1.75,27.9 \pm 24.56$ and $63.3 \pm 47.2$ eggs of $S$. cerealella). Also, the present results noticed that predatory potential of $C$. carnea was higher in the older instars of all preys than the younger ones. Balakrishnan et al. (2005) mentioned that the final instar grub consumed more number of preys compared to earlier instars. Similarly, Shrestha and Enkegaard (2013) investigated the prey preference of C. carnea ${ }^{\text {rd }}$ instar. They proved that $3^{\text {rd }}$ instar larvae of $C$. carnea had a significant preference for $N$. ribisnigri at two ratios (10 aphids: 80 thrips, 65 
aphids: 25 thrips).Up to the present results we can arrange the prey's in descending order as follows: C. cephalonica eggs, followed by $P$. gossypiella and at last $S$. cerealella eggs. This finding was surprising and unexpected as the predator $C$. carnea was reared initially and fed on $S$. cerealella eggs for its facilities and low costs.

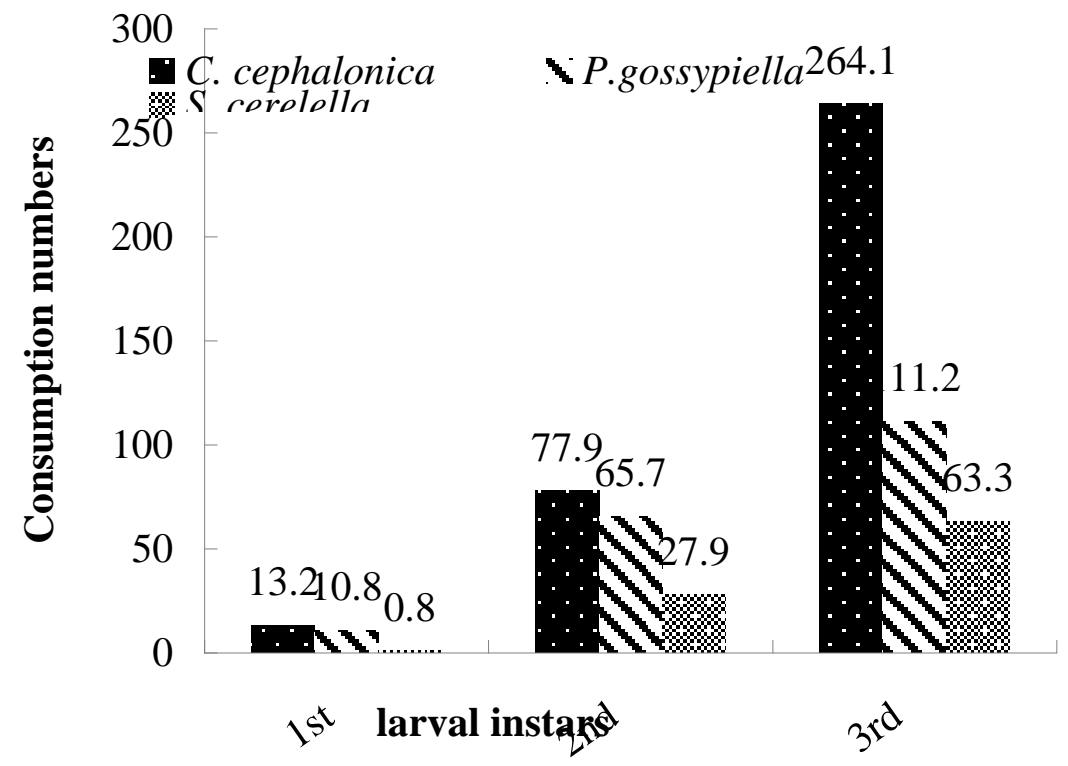

Fig (1): The three larval instars of the predator $C$. carnea upon eggs of three preys, in a free choice trial under laboratory conditions.

3- The predator attacks: Since three prey species, C. cephalonica, $P$. gossypiella and $S$. cerealella eggs were provided for $C$. carnea predation, attack numbers was recorded for the predator against each prey species. . Data in (Table3) Clarified that the highest mean number of attack was recorded against $C$. cephalonica eggs $(2.3 \pm 1.21,3.17 \pm 1.17$ and $3.57 \pm 1.27)$ for the three larval instars of $C$. carnea, respectively, followed by $P$. gossypiella eggs $(2.5 \pm 1.3,2.0 \pm 1.15$ and $2.43 \pm 1.4)$. In case of $S$. cerealella the least number of attack was recorded $(1.5 \pm 0.71,2.25 \pm 0.5$ and $2.2 \pm 0.84)$ for the three predator larval instars, respectively. Direct observations and comparisons of $C$. carnea during the three instars feeding on $C$. Cephalonia, few numbers of damaged eggs were left after each attack; this number of damaged eggs was not consumed for feeding. The present outcome might support that $C$. cephalonica eggs is more desirable for $C$. carnea larvae than $P$. gossypiella and $S$. cerealella eggs. The personal observations through the present trials concerning number of attacks exhibit that although, $S$. cerealella eggs recorded the least desirable for the predator (the least number of attacks) it recorded the highest number of damaged eggs (not completely eaten). Finally, numbers of damaged eggs (not completely eaten) and number of attacks is not completely understood and need more studies to be clarified. 
Hassan,K. A.

Table (3): Mean numbers of attacked eggs of the three preys by $C$. carnea under laboratory conditions.

\begin{tabular}{|c|c|c|c|}
\hline \multirow{2}{*}{ instars } & \multicolumn{3}{|c|}{ Mean No. of attacked eggs \pm S.D. } \\
\cline { 2 - 4 } & C. cephalonica & P. gossypiella & S. cerealella \\
\hline 1st & $2.3 \pm 1.21$ & $2.5 \pm 1.3$ & $1.5 \pm 0.71$ \\
\hline 2nd & $3.17 \pm 1.17$ & $2.0 \pm 1.15$ & $2.25 \pm 0.5$ \\
\hline 3rd & $3.57 \pm 1.27$ & $2.43 \pm 1.4$ & $2.2 \pm 0.84$ \\
\hline
\end{tabular}

${ }^{*}$ Means followed by the same letter at the same row are not significantly different at $P=$ 0.05

\section{REFERENCES}

Abd El-Hafez, Alia; A.G. Metwally and M.R.A. Saleh (1982): Rearing pink bollworm Pectinophora gossypiella (Saund.) on kidney bean diet in Egypt (Lepidoptera: Gelechiidae). Res. Bull., Fac. Agric., Zagazig Univ., April, No.576, 10pp.

Balasubramani, V. and M. Swamiappan (1994): Development and feeding potential of the green lacewing Chrysoperla carnea (Stephens) (Neuroptera: Chrysopidae) on different insect pests of cotton. Anz. Schardlingsk. Pflaanzensch. (Germany) , 67: 165-167.

Balakrishnan, N., R.K. MuraLi Baskaran and N.R. Mahadevan, (2005): Development and predatory potential of green lacewing Chrysoperla carnea (Stephens) (Neuroptera: Chrysophidae) on different prey insects. Agric. Sci. Digest, 25 (3): 194-197.

Hassan, S.A., (1995): Improved method for the production of the angoumois grain moth, Sitotroga cerealella (Oliv.). (Trichogramma and other egg parasitoids conference, Cairo, Egypt, October 4-7, 1994, ed INRA, Paris, 157-160).

Mannan, V.D., G.C. Varma, and K.S. Barar (1997): Biology of Chrysoperla carnea (Stephens) on Aphis gossypii (Glover) and Myzus perisicae (Sulzer). J. Insect Sci., 10: 143-145.

McEwen, P., New, T.R. and Whittington, A.E. (2001): Lacewing in the Crop Environment (Cambridge University Press, Cambridge.

Obrycki, J.J., M.N. Hamid, and S.A.Sajap (1989): Suitability of corn insect pests for development and survival of Chrysoperla carnea and Chrysopa oculata (Neuroptera: Chrysopidae). Environ. Ent. 18: 11261130.

Osman, M.Z. and Selman, B.J. (1996): Effect of larval diet on the performance of the predator Chrysoperla carnea (Stephens) (Neuroptera: Chrysopidae). J. Appl.Ent.120, 115-117

Ridgway, R.L.and W.L.Murphy (1984): Biological control in the field. In: Biology of Chrysopidae (eds. M. Canard, Y. Semeria and T. R.New). Junk, Boston, pp. 220-228.

Shrestha, G. and Enkegaard, A. (2013): The green lacewing, Chrysoperla carnea: preference between lettuce aphids, Nasonovia ribisnigri, and western flower thrips, Frankliniella occidentalis. J. of insect Sc.(Madison) Vol. 13, Number 94. 
Snedecor, G. W. and W. G. Cochran (1980): Statistical Methods, 2nd Ed. The lowa State Univeristy Press, Ames, lowa, pp. 318.

Singh, N.N. and K. Manoj (2000): Potentiality of Chrysoperla carnea in suppression of mustard aphid population. Ind. J. Ent., 62: 323-326.

Syed, A.N., M. Ashfaq and S. Khan (2005): Comparison of development and predation of Chrysoperla carnea (Neuroptera: Chrysopidae) on different densities of two hosts (Bemisia tabaci, and Amrasca devastans). Pak. Entomol. 27 (1): 41-44.

Uddin, J., N.J. Holliday, and P. A. Mackay (2005): Rearing lacewings, Chrysoperla carnea and Chrysopa oculata (Neuroptera: Chrysopidae), on prepupae of alfalfa leafcutting bee, Megachile rotundata (Hymenoptera: Megachilidae). Proc. entomol. Soc. Manitoba, 61: 1119.

Venkatesan, M., S.P Singh and S.K. Jalali (2000): Rearing of Chrysoperla carnea (Stephens) (Neuroptera: Chrysopidae) on semi-synthetic diet and its predatory efficacy against cotton pests. Entomology, 25: 81-89.

Venkatesan, T., S.P singh, S.K Jalali,. and S.Joshi, (2002): Evaluation of predatory efficiency of Chrysoperla carnea (Stephens) reared on artificial diet against tobacco aphid, Myzus persicae (Sulzer) in comparison with other predators. J. entomol . Res., 26: 193-196.

Yuksel, S. and Goemen, H., (1992): The effectiveness of Chrysoperla cranea (Stephens) (Neuroptera: Chrysopidae) as a predator on cotton aphid, Aphis gossypii (Glov.) (Homoptera: Aphididae). Proc. Second Turkish Nat. Congr. Ent., pp. 209-216.

Zaki, F.N. and M.A. Gesraha (2001): Production of the green lacewing, Chrysoperla carnea (Steph.) (Neuroptera: Chrysopidae) reared on semi-artificial diet based on algae, Chlorella vulgaris. J. appl. Ent. 125: 97-98.

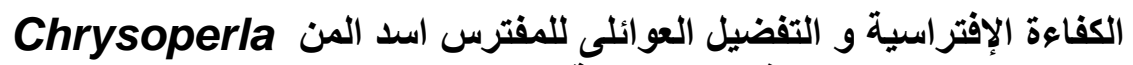
carnea كارم أبوزيد حسن على تلي معهز بحوث وقاية النباتآت ـ مركز البحوث الزراعية ـ الدقي- جيزة

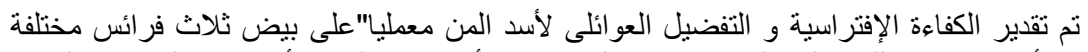

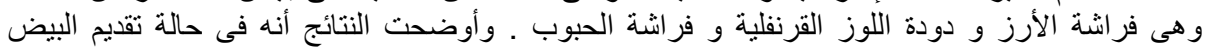

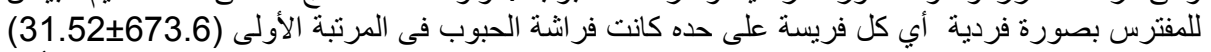

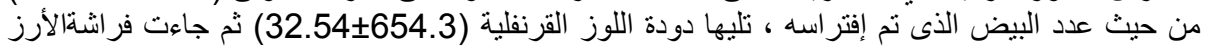

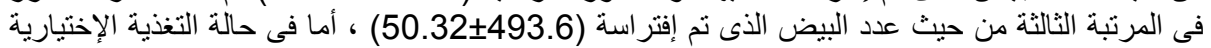

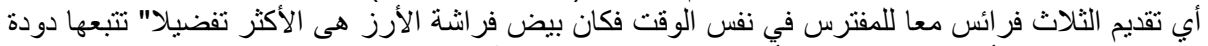

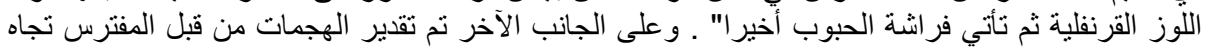

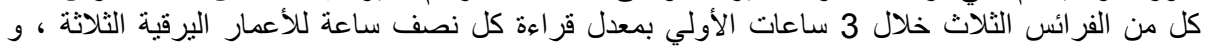

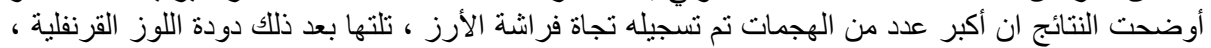

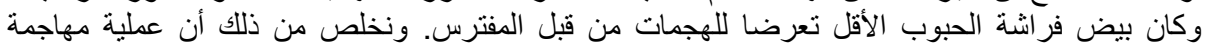

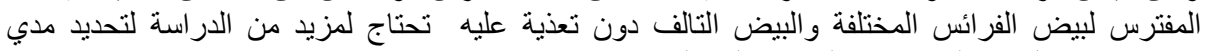

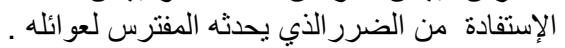

